\title{
'Are we to become a gender university?' Facets of resistance to a gender equality project
}

\author{
Stina Powell ${ }^{1}$ (D) | Malin Ah-King ${ }^{2}$ | Anita Hussénius ${ }^{3}$
}

${ }^{1}$ Department of Urban and Rural Development, Swedish University of Agricultural Sciences, Ulls väg 28, 75007 Uppsala, Sweden

${ }^{2}$ Department of Ethnology, Comparative Religion and Gender Studies, Stockholm University, Stockholm, Sweden

${ }^{3}$ Centre for Gender Research, Uppsala University, Uppsala, Sweden

\section{Correspondence}

Stina Powell, Department of Urban and Rural Development, Swedish University of Agricultural Sciences, Ulls väg 28, 75007 Uppsala, Sweden.

Email: Stina.Powell@slu.se

\begin{abstract}
Gender equality (GE) is something 'we cannot not want'. Indeed, the pursuit of equal rights, responsibilities and opportunities for all women and men throughout a society freed from gendered oppression is widely visible in recent organizational GE initiatives. In practice, however, GE initiatives often fail in challenging gendered norms and at effecting deep-seated change. In fact, GE measures tend to encounter resistance, with a gap between saying and doing. Using a GE project at a Swedish university, we examined the changing nature of reactions to GE objectives seeking to understand why gender inequality persists in academia. We used 'resistance' to identify multiple, complex reactions to the project, focusing on the discursive practices of GE. Focusing our contextual analysis on change and changes in reactions enabled a processoriented analysis that revealed gaps where change is possible. Thus, we argue that studying change makes it possible to identify points in time where gendered discriminatory norms are more likely to occur. However, analysing discursive practices does not itself lead to change nor to action. Rather, demands for change must start with answering, in a collaborative way, what problem we are trying to solve when we start a new GE project, in order to be relevant to the specific context. Otherwise, GE risks being the captive of consensus politics and gender inequality will persist.
\end{abstract}

\section{KEYWORDS}

academia, gender equality, meritocracy, resistance

\section{1 | INTRODUCTION}

Gender equality (GE) is something 'we cannot not want' (Brown, 2000, p. 238). Indeed, the pursuit of equal rights, responsibilities and opportunities for all women and men throughout a society freed from gendered oppression 
(Lombardo, Meier, \& Verloo, 2009; Verloo \& Lombardo, 2007) is widely visible in recent organizational GE initiatives. In practice, however, GE initiatives often fail in challenging gendered norms and at effecting deep-seated change toward the above-mentioned goals. In fact, GE measures tend to encounter resistance (Mergaert \& Lombardo, 2014; Pincus, 2002), with a gap between saying and doing (Powell, 2016). The following research sought to identify such resistance and the changing nature of reactions to GE objectives, by using a GE project at a Swedish university that included an examination of reactions within hosts/researchers and participants alike. Importantly, the point of entry of resistance, which tends to either focus on an explanation for its origins (e.g., Mergaert \& Lombardo, 2014; van den Brink, 2015) or understand behaviour, was limiting for this research inasmuch as a greater range, complexity and diversity of reactions, including resistance, explain why gender inequality persists in academia.

First, a definition of GE is needed beyond its above stated political goals of equal opportunities. We are aware of its contested notion within policy, civil society and amongst academics (Liinason, 2010; Verloo \& Lombardo, 2007). Gender equality is attributed different meanings depending on context, purpose and whether it is perceived as a political goal, a vision or both. In this study, GE was viewed as a political field dealing with the problem of gender inequality, between women and men, but also discrimination by, for example, class and race (Honkanen, 2008; Mählck, 2013).

We used 'resistance' to identify multiple, complex reactions to the aims of the GE project, focusing on the specific, multiple discursive practices of GE at the Swedish University of Agricultural Sciences (SLU). The project was launched and implemented in an academic setting, where meritocracy is a strong belief. Studies have shown that GE in academia is particularly difficult to achieve, one reason being that meritocracy permeates academia (Alnebratt \& Jordansson, 2011; Espersson, 2014). Meritocracy has flaws and may even increase rather than decrease inequalities (Powell, 2016). In a meritocracy, the best and most hardworking are promoted and thus, GE aims may be considered unnecessary, as inequalities are difficult to explain other than by individual failure and inadequacy (Lawton, 2000). Here, we focused on ambiguities of resistance expressed by actors in different positions during the project, seeking to understand why gender inequality persists in academia. We applied a discursive practices approach (Bacchi \& Bonham, 2014), by analysing what was said and done in relation to its specific context. In discursive practices, resistances arise from clashes between contradictory subject positions and practices (Thomas \& Davies, 2005). Thus, discursive practices are not necessarily openly expressed or visible, but rather subtle, situated and contextual. The strength with this approach is that it uncovers power relations by revealing whose knowledge and positions count, for example, how certain things are expressed and how acceptance of things said and done depends on when and by whom they are expressed (Thomas \& Davies, 2005).

The research questions were: what were the reactions when the project was introduced and carried out?; and who reacted and how? To contribute to theory, we also asked: how can these reactions be explained as discursive practices (what can be said, thought and done and by whom in the specific context)?

\section{2 | SETTING THE SCENE}

Gender equality is part of a cherished political ideology in the Nordic countries, which often view themselves as demonstrating 'best practice' (Skjeie \& Teigen, 2005, p. 188). As part of Swedish national identity and self-image (Arora-Jonsson, 2009; Melby, Ravn, \& Carlsson Wetterberg, 2009), GE policy (e.g., Discrimination Act, 2008:567) applies to all areas of society, including higher education institutions. Universities therefore need to act on gender inequalities. In 2010, the SLU received government funding to run a GE project. The reactions to the GE project were context specific and situated, so a short description of SLU is necessary. It is a predominantly natural sciences university hosting research and education in veterinary science and agronomy, but also in interdisciplinary areas such as environmental communication and rural development and applied research in the green sectors (agriculture, forestry, landscape and environmental management). In the past 20 years the focus has changed from productivity to sustainability and environmental management, resulting in more social science and interdisciplinary research and education at SLU (Bothmer, Carlsson, \& Jennische, 2012). Regarding GE, SLU struggles with gender-segregated 
degree programmes, low numbers of female professors and gender discrimination issues (Powell, 2008). Previous initiatives on gender inequalities at SLU framed GE as a problem for individual women (Powell, 2016), something which led to activities intended to increase the number of female professors and to resolve gender-segregated education programmes by encouraging women in male-dominated subjects such as forestry (Annual Reports 1994-2014). For education, the goal expressed in the 2012-2016 strategy was to work long term on GE awareness and broaden the student recruitment base (SLU, 2012, p. 43). When the GE project was launched, it complied with these strategies and was well timed, as SLU had very few GE-related activities at that stage. The project differed in approach from previous GE measures by going beyond GE as a problem for individual women to focus on enhancing the study environment and teaching practices by development and provision of a gender and norm-critical pedagogy course for teaching staff (Powell \& Ah-King, 2013). Thus, it introduced new problem identifications for gender inequalities.

There is much literature on why inequality persists in academia. Below, we draw on parts of it to empirically place our research.

\section{I GENDER EQUALITY IN ACADEMIA}

Academia has been described by feminist researchers as hierarchical and discriminatory (Bacchi \& Eveline, 2010; Benschop \& Brouns, 2003; van den Brink \& Benschop, 2012). These feminist studies bring important perspectives to our case, for example, the different ways in which patterns of discrimination develop, how women and men are subjectified and stereotyped in academia, what GE means as a concept and when put into practice, and the relationship between GE and meritocracy. All of these studies bring clues to how and why gender inequality persists and clues to understanding why there is resistance to GE in academic institutions.

It has been argued that daily, seemingly small, practices may create patterns of discrimination as they, when repeated, become part of formal and informal institutional practices (Husu, 2001; Mergaert \& Lombardo, 2014; Treleaven, 1998). The creation and upholding of discriminatory patterns involve stereotypical ideas about women and men and their suitability for academia, for example, that women (unlike men) prioritize family over work or are unsuited to the long hours and dedication associated with academia (Benschop \& Brouns, 2003; Wullum Nielsen, 2015).

That academia is hierarchical and discriminatory also leads to attempts to do something about it. Different measures are built on different understandings of what GE is and for whom measures are introduced. In recent years, there has been an increased interest amongst feminist scholars to analyse the concept of $G E$ as it is sometimes unclear what GE means, the problems GE measures are intended to solve and who is included/ excluded in discussions on inequalities (Lilja \& Johansson, 2013; Magnusson, Rönnblom, \& Silius, 2008; Mählck, 2013). Liinason (2010) and Honkanen (2008) argue that the Nordic discourse on GE reproduces the womanman binary, thereby silencing other forms of discrimination based on, for example, race, class or sexuality. They argue both that through the woman-man dichotomy, GE policy in reality entails attempting to improve the situation for white, heterosexual, middle-class women (Liinason, 2010; Honkanen, 2008). In this way, the concept itself contributes to maintaining inequalities.

Depending on the way that the problem of inequality is formulated, there will be a turn towards the political or the administrative in trying to find a solution (Lombardo et al., 2009). And it appears as if GE has become increasingly depoliticized through administrative routines, such as Gender Mainstreaming (GM) or Affirmative Action (AA), and thereby losing its political agenda. Acker (2006), for example, argues that AA programmes have become 'mere bureaucratic paper shuffling in most organizations' where the outside drive for GE, as well as the organization for GE within organizations have decreased (p. 456). Acker further refers to white men claiming reverse discrimination as a result of measures such as AA, a claim which returns also in our data (Acker, 2006). Attempts to implement GE measures through GM is associated with neoliberal governing of universities, in so-called line organizations commonly ascribed to the private sector (Bacchi \& Eveline, 2010). As convincing as GM rhetoric might be with its ambition to 
change the organization rather than the individual, it builds on assumptions that inequality is a matter of lack of knowledge about discrimination and not a matter of power and privilege (Lombardo \& Mergaert, 2013). Following this, there is a tension between an administrative and neoliberal way of managing GE (based on individualization, competition, meritocracy and market orientation) and a feminist understanding of GE in which structural explanations for inequalities and a need for political change are stressed (Carbin \& Rönnblom, 2012; Edenheim \& Rönnblom, 2012; Eduards, Jansson, Wendt, \& Åse, 2012).

In the light of the above, we draw the conclusion that there is a need to pay attention to the way in which gender inequality is defined and/or understood in academia in order to make visible patterns of discrimination. As there is seemingly no one way of explaining why inequalities persist, we argue for the need to analyse change and the complexities of reactions to and understandings and implementation of GE. This will bring a more multifaceted picture to the literature on GE in academia. Following this, we now turn to how resistance and resistance to GE in academia have been analysed.

\section{4 | THEORETICAL APPROACHES TO UNDERSTANDING RESISTANCE}

Our understanding of 'resistance' as discursive practices follows Hollander and Einwohner (2004, pp. 547-549) who see resistance as a socially constructed concept that is complex and ambiguous. The strength of this definition is that it draws attention to power dynamics and how resistance is discursively practised and influenced by who is interacting and under what circumstances. Resistance can be actively exercised in one situation but expressed or simply implied in another through neutrality or indifference (Hollander \& Einwohner, 2004).

The use of the term 'resistance' in sociological research is both imprecise and diverse (Hollander \& Einwohner, 2004), and tends to either demonize or celebrate resistance (Hardy \& Clegg, 2006). These perspectives reoccur in studies investigating resistance to GE in academic organizations. For example, interpreting resistance as a problem to be overcome leads to attempts to 'educate away' faulty or mistaken ideas or as an opportunity or an opening to be utilized in order to overcome the resistance (Ford, Ford, \& D'Amelio, 2008; Ford \& Laurie, 2009). Without disregarding the insights of these studies, we found it more useful in our analysis to interpret resistance as discursive practices, that is, as context specific. Thus, resistance in one context may not be considered the same way in another, and resistance is accomplished through co-construction of meaning (Thomas \& Davies, 2005).

Feminist literature on resistance to GE includes studies of how gender perspectives and GE measures have been received in organizations (e.g., Connell, 2005; Mergaert \& Lombardo, 2014; Pincus, 2002; van den Brink, 2015). For example, these studies ask what the reasons behind resistance are (Connell, 2005), what analysing resistance can tell us about defensive routines and how resistance can be a key to understanding why GE implementation is ineffective (Benschop \& Verloo, 2006; van den Brink, 2015). These studies build on an assumption that by studying resistance we can learn something useful for more successful implementation of GE agendas in academia. In this study, we would expand by saying that we need to study not only resistance, but all kind of reactions to GE. The complexity of reactions (from resistance to engagement and indifference) might bring new knowledge and a wider understanding than a narrower focus on expressions of resistance solely.

Feminist studies have brought attention to different aspects of when and why there is resistance to GE. These include, for example, the role of leaders (Husu, 2005; van den Brink \& Benschop, 2014), how feminist knowledge is considered in a structure where this is not seen as 'proper knowledge' (van den Brink, 2015) and how ideals of meritocracy undermine efforts to pursue GE in academia (Powell, 2016; Bagilhole \& Goode, 2001; Gutiérrez y Muhs, Niemann, Gonzalez, \& Harris, 2012).

The role of leaders has been researched in studies on gatekeepers in European Union (EU) research funding committees (Husu, 2005) and academic recruitment processes (van den Brink \& Benschop, 2014). In both studies, leaders played an instrumental role in the reproduction of inequality in academia. In Mergaert and Lombardo's (2014) study of the implementation of GM in EU research policy, they also saw the role the highest institutional levels 
play in the implementation. They showed how lack of support for GE capacity building had its origins in implicit resistance, where decisions on prioritizing agendas are taken and resources distributed. Similar to our way of understanding resistance as 'done' in practice, Mergaert and Lombardo define resistance as a phenomenon which emerges during processes of change. In their analysis they identified four categories of resistance: individual, institutional, formal and informal. Individual resistance is expressed by an individual's action/inaction, while institutional resistance is a pattern of action/inaction that is systematically repeated and collectively orchestrated (Mergaert \& Lombardo, 2014, p. 9). Formal resistance is, for example, organizational structure and regulations that counteract the aims of GE. Informal resistance relates to the organizational culture and the norms, interactions, symbols and behaviour of the institution and mediated by its representatives (Mergaert \& Lombardo, 2014). While the scope of Mergaert and Lombardo's (2014) study differed from ours, the study was helpful as it revealed how resistance is practised at different levels in an organization. It also showed how formal and informal resistance is embedded and practised by individuals in interaction.

Another topic related to why inequalities persist in academia is how meritocratic principles permeate academic cultures. Studies suggest that norms of meritocracy are an important reason why gender discrimination prevails in academia (Alnebratt \& Jordansson, 2011; Powell, 2016; Bagilhole \& Goode, 2001) and that evaluations of merit and excellence are not value-neutral practices but influence opportunities for women and men in academia depending on skin colour and class (Gutiérrez y Muhs et al., 2012; Sandström, Wold, Jordansson, Ohlsson, \& Smedberg, 2010). Norms of the excellent researcher are influenced by essentialist ideas. For example, when studying recruitment processes in Denmark, Wullum Nielsen (2015) found that some heads of department expressed views indicating that women were not suited to academia due to its competitive nature, individualism and long working hours. Similar findings have been reported by, for example, van den Brink, Brouns, and Waslander (2006) and Benschop and Brouns (2003). Also in our data, we found these types of discourses and we considered these types of essentialist ideas a form of resistance to achieving GE aims. If these essentialist ideas exist in an organization, they are also likely to contribute to inequality. And, as Wullum Nielsen (2015) shows, the criteria for judging merit were established by existing power groups, resulting in dominant perspectives being perpetuated and patterns of inequality being maintained.

Summing up, feminist scholarship brings attention to different aspects of what Acker (2006) has named 'inequality regimes', that is, 'loosely interrelated practices, processes, actions, and meanings that result in and maintain class, gender, and racial inequalities within particular organizations' (p. 443). Next, we present the case study and the methodological point of departure for this study.

\section{5 | THE GENDER EQUALITY PROJECT}

The aim of the GE project at SLU was to integrate gender and norm-critical perspectives into teaching and subject content and thereby challenge gendered norms at the university. The main project activity was a course on gender and norm-critical pedagogy, which was attended (voluntarily) by 55 teaching staff. The course focused on developing gender- and norm-sensitive teaching practices. All project activities were developed by a reference group and led by a project group (comprising project leader, course leader, pedagogic developer and gender researcher). The present analysis was based on material collected during the GE project, from planning to completion (Figure 1).

\section{6 | EMPIRICAL DATA AND METHODS OF ANALYSIS}

The empirical data were from three different phases: planning (year 1), implementation (years 1 and 2) and follow-up (year 3) (see Figure 1). 

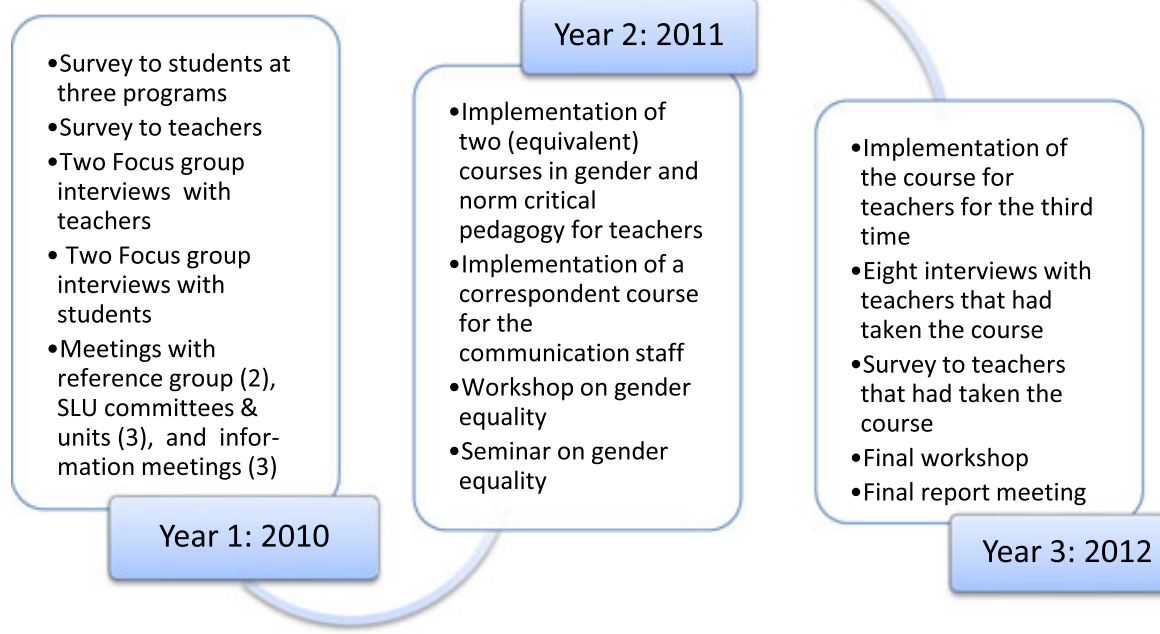

FIGURE 1 Overview of activities provided in the GE project [Colour figure can be viewed at wileyonlinelibrary. com]

\section{1 | Phase I}

- Survey with students (900 students, 82 responses) in three degree programmes regarding the extent to which GE or gender perspectives were included in their education at that time

- Survey with teachers (80 teachers, 27 responses) regarding if and to what extent GE and gender perspectives were included in their teaching practices

- Two focus group (FG) interviews. The participants responded to a request sent out with the survey asking for participation in the FGs and were invited to the interviews by the project leader, who also facilitated the FGs. The two FGs included five students each (20-30 years old, 2 men, 8 women) from three programmes at the university. The discussion themes for the FGs were their experiences of GE at the university, their ideas of what a gender equal university education would entail, experiences of when gender has mattered in their education and what they considered prioritized areas related to GE at SLU

- Two FG interviews with six teachers (25-60 years old, 1 man, 5 women). Audio recorded and transcribed. Also here, the teachers responded to a request sent out with the survey and were invited to participate in the FGs by the project leader. The themes were the same as in the FGs with students (above)

- Meeting notes from two reference group meetings, three information meetings with teaching staff and three meetings with committees and units at SLU

- Analysis of university reports and strategies

\section{2 | Phase II}

- Participant observations of all three courses (total 48 hours, audio recorded and transcribed). The observations departed from noting reactions and responses to the gender perspectives brought up in the lectures and in the discussions, including oral comments but also body language. The researcher thus interpreted the situation and noted the comments in writing and followed up the notes taken by listening to the recordings 


\section{3 | Phase III}

- Eight follow-up semi-structured interviews with course participants (audio recorded with permission of the participants, transcribed, one to two hours). The interviewees were chosen based on being identified during the observations of courses, as being more active and engaged. As the interviews were part of the follow-up of a GE measure, the aim of the interviews was twofold: (i) to identify ways of working with GE at the university in the future; and (ii) a research interest which focused on, for example, what responses the interviewee met if/when bringing up GE and gender perspectives at their department or with students, about how they saw themselves as teachers being change agents for GE at SLU, what the obstacles and opportunities working towards GE were, how the leadership addressed GE and whether or not there was support for bringing up GE in their workplace or in their teaching practice

- Notes from four workshops with SLU leaders, students, teachers and researchers

Other empirical material was taken from a previous study (Powell, 2008). It included meeting notes and e-mail exchanges with heads of department at SLU.

Our data analysis comprised three stages. First, we recorded and took notes during interviews, meetings and FGs. In the process of data collection, a first stage of analysis was done simultaneously as we fully transcribed and coded the material. At this stage, a first tentative categorization was made of frequently occurring reactions to GE and gender perspectives in the organization. In the second stage, we re-read the material and discussed the initial categorizations and conducted a more thorough categorization in the process. Themes emerged in the process and we were able to form emerging themes.

The process of statement categorization can provide insights about a certain situation at a specific time and context, but is embedded in larger historical and social patterns (Arora-Jonsson, 2005). In the present case, it revealed information about SLU, but also about gender inequality and why it persists in academia in general.

\section{7 | METHODOLOGICAL STARTING POINTS}

Using this material, we examined what the reactions to the GE project say about gender inequalities at the university. The analysis was qualitative and did not attempt to produce generalizable results on all students and teachers at SLU, but rather to explore ideas and topics from people in the organization regarding responses to GE and gender perspectives in education. During the analysis we aimed to be transparent and recognize that our analysis may have been coloured by the moral and political values we hold as feminist researchers wishing to raise awareness and challenge gendered norms in academia. For example, as we analysed comments about the relevance of feminist perspectives on the subject areas of SLU, which are mainly natural science based, we needed to consider, for example, that what we interpreted as resistance to feminist perspectives also could be lack of training in seeing these perspectives. The course for teachers included a session on feminist perspectives on natural sciences and during these sessions there was often an 'aha-moment' where participants reflected on, for example, how research is formulated and by whom. These questions appeared to be new to the course participants and in the light of this, we can see how our own knowledge of how gender matters in research processes was not common knowledge previous to the course. Following this, our interpretation of reactions as resistance needed to be thoroughly analysed to allow different interpretations.

When analysing the responses to the GE project and its aims, we viewed the responses and reactions as discursive practices. Discourse has been defined as: 'what can be said, and thought, but also who can speak, when, where and with what authority' (Ball, 1990, pp. 17-18). Thus, discursive practices are how people practise discourse, linked to the symbolical, political and material in a particular social and historical context (Bacchi \& Bonham, 2014). As discursive practices, the responses to the GE project became visible and possible 
to analyse, in order to examine why gender inequality persists in academia, but also where the possibilities for change emerge.

All field notes and transcribed audio-recorded data were initially categorized according to those who had been involved in the project: students (surveys, interviews, FGs, committees), teachers (planning process, survey), course participants (course, interviews, FGs) and leadership representatives (project-related activities). A first phase of analysis started and was carried through continuously as empirical data were collected during the project. It began with repeated readings, in order to create an intimate knowledge of the empirical material. The first round of coding examined the reactions expressed when the project was introduced and implemented, by whom and how these reactions were expressed. The following stage identified situations interpreted as resistance. Thereafter the analysis examined the reactions as discursive practices, that is, how the organization, with its norms, values and formal structures, enabled certain reactions but not others and whether SLU reflects the larger discourse on GE in academia described in the literature. The analysis then moved between the formulation of broader themes and the identification of subthemes in an iterative fashion, allowing the identification of sub-themes to reformulate and sharpen the broader themes. This empirically driven coding provided an overview of the material and served as the foundation for the next round of more focused analysis. Finally, we identified overarching themes: (i) naturalized ideas about women and men and their suitability for an academic career; and consequently (ii) a clash between the formal and informal GE discourses in the organization. From the second of these themes we could see a link to a third theme: (iii) challenges to the gender status quo. These in turn led to themes (iv) questioning the relevance of feminist knowledge to the university; (v) the influence of the discourse that GE is ethically the 'right thing to do'; and how this discourse played out in terms of (vi) responsibility-displaying leadership dilemmas.

\section{I RESULTS: FACETS OF REACTIONS}

The results are presented in the form of snapshots and show reactions in a particular moment and context, rather than a complete account of all incidents that appeared in each category. They represent the discussions and ideas prompted by the project, rather than the project per se.

\section{1 | Women are, men are ... discourses of suitability}

Previous research has shown that there are discourses revealing what is considered possible for women and men in academia (Benschop \& Brouns, 2003; van den Brink, 2015; Wullum Nielsen, 2015). In this study, such discourses mainly concerned academic careers. Ideas of naturalized choices of women were frequently present and were both an explanation and an excuse for the low number of female professors at SLU: 'Women lag behind because they start families when they are between 30-40 years old, which coincides with the first phase of their academic career.' This comment was made by the vice chancellor of SLU at a seminar on postdoctorate career paths. Similarly, in another meeting a representative from the equal opportunities organization explained the low number of women in higher academic positions: 'Once women have a family, they don't want a career.' This comment is particularly troublesome as the speaker was engaged in working against gender discrimination, but reiterated the idea that gender inequality is naturalized with women's preference for children over career. This discourse was also expressed in an article in the SLU staff magazine (17 June 2015) in relation to the situation for female PhD students at the Department of Ecology. In a small study conducted at that department, one finding was that women with children did not see themselves as staying in academia. This was not associated with discrimination against women, but with women having children SLU staff magazine, 17 June, 2015 However, from another frame of analysis, it could be interpreted as meaning that women with children did not consider it possible to stay in academia owing to difficulties with the organization's culture.

The comments above exemplify assumptions that women's individual choices are the reason for them lagging behind, rather than organizational norms and assumptions creating discrimination (Powell, 2016; Wullum Nielsen, 
2015). These reactions fall within a larger discourse at SLU that has prevailed since at least 1994 whereby gender inequality is explained and discussed in terms of women's lack of self-confidence or being more family oriented than men (Powell, 2016). For example, SLU policy states that young researchers, especially women, should be given university support during their early academic career to ensure they do not lag behind their male colleagues (SLU, 2012). However, the same document also acknowledges that inequality is a structural rather than individual concern, which suggests that a counter-discourse exists. The present analysis found less prevalence of this discourse. The reactions observed displayed support for GE as a vision, but was undermined by attributing differences in careers to ideas about women's and men's 'natures'.

\subsection{Clashes between formal and informal discourses of gender equality}

In order to analyse the discourse explaining gender inequality as an individual concern for women and the counter-discourse citing structural explanations, we drew on research describing how formal structures and informal norms and cultures influence discursive practices of GE (Bacchi \& Bonham, 2014; Mergaert \& Lombardo, 2014). The formal aspects of a university (strategies, organization, priorities) influence and are influenced by informal cultures and norms (Bacchi \& Bonham, 2014; Mergaert \& Lombardo, 2014). When examining this in the present case, we focused on reactions originating in formal institutional procedures, for example, as expressed in decisions taken (or not taken). An issue related to formal structures is formal responsibility, which we also examined. We found a clear cycle in reactions to the project, with an initial tendency for support and a later tendency for resistance. The examples presented in Table 1 show the complexity of the reactions, ranging from a will to act among high-level representatives (of the formal organization) to engagement being circumscribed in practice. We attributed this to a clash of discourses. Importantly, we also interpreted these reactions as being embedded in the GE discourse in Sweden, where GE is 'the ethically right thing to do' at universities (Powell \& Arora-Jonsson, 2015).

Concerning the project placement (Table 1), the overall responsibility for GE at SLU lies with the vice chancellor's office. Placing the GE project at SLU's central administration would have sent a signal to the organization that it was important. Instead, it was placed in the home department of the project leader, a social sciences department at a mainly natural sciences university. This can be interpreted as a way of decoupling GE from the central administration (Espersson, 2014). Through the decision to place the project at the department, the university showed that it had taken action on the issue, while at the same time decoupling it from decision-making power. This represented a lost opportunity to make a convincing statement that GE is important, but also shifted the burden of justifying why gender matters to others.

The withdrawal of university co-funding (Table 1), which had been guaranteed in the project application, was announced only a few months before the first course was scheduled, with the explanation that co-funding would lead

TABLE 1 Complexities of formal resistance to the GE project at SLU

Support Resistance

A pro-vice chancellor approved to host the GE project at SLU and took part in writing the application (2010)

In the application, SLU agreed to co-fund the project with SEK 700,000 (2010)

Identifying gender pedagogics as a key component in SLU strategy (2013)
When the Project Leader requested that the project would be placed at the central university administration (where the main responsibility for GE belongs), this was turned down. The reason being administrative difficulties. The project was instead placed at one of two social science departments at the university, the home department of the Project Leader

This offer was withdrawn at the first reference group meeting. In a follow-up discussion after the meeting, administrative difficulties were given as an explanation

Restricting the measures to a half-day workshop called 'gender-Sensitive Pedagogics' given by the education division. This workshop was never given and was soon removed from the courses offered to teachers at SLU 
to administrative difficulties. The late timing of the withdrawal was a major setback for the project and raised concerns not only about the signal it sent, but also about the possible scope of the project. Our initial intention was to run a pilot project involving most SLU teaching staff in three highly gender-segregated education programmes, in order to build up a critical mass of teachers who could develop norm-critical pedagogics in their degree programmes. We intended to use these experiences to refine the course and offer it to all teachers at SLU. With the withdrawal of co-funding, the course was opened up to all teachers at SLU from the start, including those located at campuses in other parts of Sweden. Some supplementary funding was later provided to a department that had many teachers participating in the course and we also obtained funding for an intensive course.

A critical failure occurred at the end of the project, when it was reported and handed over to the Committee for Education at SLU. This Committee was given the task of providing a workshop for teachers in gender-sensitive pedagogics, but made no contact with project staff to obtain insights from the project in performing this task. Three years later, the workshop has still not been held (Table 1) and it is not mentioned in the 2015/2016 catalogue. This exemplifies how GE can be sidelined through passing responsibility to individuals or sub-units that lack the mandate or interest to pursue the issue. In terms of resistance as discursive practices (Thomas \& Davies, 2005), this showed how contradictory roles and practices can create a clash in an organization when it comes to accommodating GE work and the perspectives it brings. One such clash relates to the moral obligation for GE in the Swedish context (Powell \& Arora-Jonsson, 2015), where the ethical frames of GE simultaneously enable and limit what can be done, as shown above. Honkanen (2008) argue that the consensus on GE is closely connected to GE policy reproducing certain heteronormative equality. Below, we present the discourse that emerges under the GE umbrella when the gender status quo is challenged.

\subsection{Challenging the gender status quo}

As mentioned, GE at SLU is often framed in a discourse where women are to be 'fixed' through projects and programmes aimed at increasing their self-confidence or ensuring they can gain merits even if they have children. The GE project analysed here was different, as it introduced a norm-critical approach which did not take its starting point in numerical inequalities, but in norms and values. This approach gave rise to reactions indicating that it challenged the prevailing discourse of gender inequalities in the Nordic countries (Honkanen, 2008; Liinason, 2010). Mergaert and Lombardo (2014) describe this as resistance aimed at preserving the gender status quo. The reactions below show reproduced heteronormativity as the gender status quo at SLU.

The first reaction, which was rather unfortunate, was when a member of the project reference group joked: 'You had better not use short-haired lesbian lecturers talking about gender power relations.' This comment was not presented as his own idea, but rather as something others in the university might think. Comments like these can be powerful in the reproduction of what GE is and who has the mandate to speak about it within an organization. Critical feminist scholars such as Honkanen (2008) and Liinason (2010) argue that GE practices as implemented by governments and organizations reproduce the heterosexual norm and thereby silence 'others'. How GE becomes a matter of women and men and about certain types of masculinities and femininities was reflected in an interview with a male teacher who had taken the course in gender and norm-critical pedagogics. He worried about letting GE go 'too far', as he put it.

He claimed that women leaders at SLU have adopted typically 'male' leadership traits and that the men have had to stand back. He said: 'We have so many kind soft men here. I can't say that ... Yes, I miss men! I miss real men!' He also described being in a meeting with no women present thus:

Darn, it was nice that we were only men doing this! ... I have to say I think the gender balance at SLU is a bit too much. Maybe too much, but still ...

He appeared to believe that women had taken over, leading to a lack of 'real men' who have not been 'demasculinized' by GE. In different ways, the respondents cited above expressed resistance to GE aims beyond what they considered 'enough' at SLU. The first example shows how the ideas introduced by the GE project challenged this person's ideas of 
what GE should be, which in turn prompted reactions that can be interpreted as trying to maintain a gender status quo in which there are 'real' men. The second example shows there is a particular type of preferred masculinity and femininity and that when this is exceeded, GE is seen as going too far. A related issue is questioning the relevance of feminist knowledge.

\subsection{Questioning the relevance of feminist knowledge}

This category concerned reactions that embed what is/is not and what can/cannot be part of a specific academic context (van den Brink, 2015). SLU is a natural sciences university driven by quantitative rather than qualitative research and positivist rather than interpretivist research traditions (Powell, 2016). In this context, the introduction of gender perspectives originating from social science and social constructivist thought encountered opposition and denial of their relevance. Such reactions came from both students and leadership representatives and were expressed in anonymous surveys, not in interviews or FG discussions. Considering the discourse on GE in Sweden (Powell \& Arora-Jonsson, 2015), this greater openness in anonymous surveys than in face-to-face encounters is unsurprising. In the e-mail survey with heads of department, one person responded:

This thing with gender is not so straightforward ... it can be argued that [our department] is an area where it a gender perspective is not possible. I am personally very convinced about that. When it comes to education, we do not have a gender perspective on that. I'm sure it's debatable whether it is right or wrong, or even possible, to have a gender perspective on education, but I do not think it benefits the students in [our] case.

This standpoint suggests that it is not appropriate (or possible) to include gender perspectives in natural science research or teaching. Similarly, Liinason (2014) reported that attempts to introduce feminist perspectives on organizations and knowledge production can uncover assumptions about the 'right' kinds of knowledge and disciplines in academia.

During the project planning phase, we were told by a group of university teachers in a meeting that we should not assume we could teach them anything in the project. They also said it was essential that we as lecturers in the project were careful with our attitude (non-confrontational) when raising gender at SLU. It was implied that GE was not research-based knowledge but ideology and that people would get 'all worked up' if they knew gender was on the agenda. We were encouraged to avoid having 'anything to do with gender' when naming the planned course. These examples show a discourse in which gender is simultaneously reacted to as provocation and irrelevance.

Furthermore, in a meeting where the project plan was presented, an SLU leadership representative commented that while it was good that the project was happening, it was not a core SLU activity. This suggests that she considered gender perspectives and GE to be less important than scientific work (Wahl, Holgersson, Höök, \& Linghag, 2008). Thus, her comment became an act of resistance in an interaction with a project team whose aim was to promote $\mathrm{GE}$, and her reaction could be interpreted as a response aimed at toning down its relevance. For GE visions to be implemented, it matters who is resisting and who is engaged in GE (Mergaert \& Lombardo, 2014). Before discussing this, we describe the clash of discourses we uncovered on analysing the formal and informal discourses of GE at SLU.

\section{5 | Gender equality as 'the ethically right thing to do'}

Sweden prides itself at being at the forefront of GE (Arora-Jonsson, 2009; Melby et al., 2009). This discourse of excellence in GE influenced the reactions we describe in this section, which should be interpreted accordingly. SLU is not only obliged by law to take GE measures, but GE is also 'the ethically right thing to do' (Powell \& Arora-Jonsson, 2015). These formal requirements and the complexity of GE-related discourses create tension. Support from the university was initially strong, but decreased as the project neared its end. For example, when submitting the application to the external funding agency, one deputy vice chancellor was personally engaged, provided feedback via meetings 
and e-mail and acted as a representative in the reference group for the project, together with two other leadership representatives. However, her support diminished as the project progressed and as questions about university funding for continued work were raised. The two situations described below illustrate this change in reaction, which we attributed to tensions between what was considered ethically correct, what was made possible within the context and how this changed over the project duration. In the final stages of the project, a workshop was held to discuss continuing the work. Visions for the future were presented and it was suggested, for example, that all teachers at SLU should be invited to take the course, that a network should be set up to continue these discussions amongst university teachers and that a gender resource should be employed at a central level. In response, the leadership representative present commented: 'Are we to become a gender university now?' Thus, a discourse of GE being sidelined at the university surfaced in this situation. In addition, the timing of the comment (when a decision was being made on how to proceed with GE work at SLU) and the fact that it was made by someone in a leadership position had a devastating effect on the enthusiasm in the workshop and future prospects.

A similar reaction was observed when the project was reported to the Education Committee some weeks later. The student representative on the Committee, who had attended the gender and norm-critical course, mentioned the importance of SLU continuing to develop different ways of integrating gender/norm-critical perspectives, so that it could modernize and attract new kinds of students. In response, the Committee chairperson said 'Oh that was a pitch!' and moved to the next item on the agenda without further comment. One strong discourse at SLU is how GE mainly has been addressed, in policy and practice, as a matter of helping women overcome lack of merit and lack of self-confidence (Powell, 2016). The GE project at study here did not take this help-the-women-approach, but focused on challenging discriminatory gendered norms. The quote above can therefore be considered as a response to how GE has been addressed previously at SLU suggesting that the project itself challenged these norms by its contents. Moreover, considering the administrative sidelining of the project and the fact that it was externally funded, these two comments show how GE as introduced through the project challenged established discourses and was thus not considered part of everyday practice (Espersson, 2014). This again raises the issue of responsibility for GE and how this influenced reactions.

\subsection{Responsibility for gender equality: a leadership dilemma}

University leaders are important as they make decisions affecting GE and thereby 'doing gender' in everyday institutional life (Connell, 1997). It has been argued that GE needs to be addressed in relation to those in decisionmaking positions (Husu, 2005; van den Brink \& Benschop, 2014). Our material provided examples of a person 'wearing different hats', that is, expressing views in one situation and contradicting them in another. We found that this was closely connected to context, but also to accountability. One respondent initially shared personal experiences from teaching and research supporting the project aims and, when wearing this hat at this time, supported the project. However, that same respondent was hesitant to provide open support when asked for help in advertising the project. When we asked another person in an interview what he thought about the roles of leadership in regards to GE at SLU, he explained the hesitation that he had experienced with saying:

The question is then whether the leadership is afraid to bring up irrelevant issues or whether they cannot defend bringing [GE] up ... so high on the agenda ... you cannot suffer too much for these issues ... then you are not trustworthy, I think.

Thus, this interviewee interpreted actions and non-actions as a form of balancing act between contrasting roles. This can be seen as a way of navigating between the personal position (in which GE norms were important) and the position as a prominent representative of an organization (in which GE was not a priority). A leader can act as an individual, sharing personal views, and also as a representative of institutional norms and values and act on these in daily practice. In this way, 'individual and institutional responses reciprocally create each other in discursive practices' (Mergaert \& Lombardo, 2014, p. 7). The individual leader has agency that can influence what is deemed possible and appropriate. 


\section{9 | DISCUSSION: ANALYSING REACTIONS}

In the discussion we return to the two questions posed in the introduction: what were the reactions to the project?; and how can these reactions be explained as discursive practices? After the concluding remarks, we reflect on how our findings can add to practice and what remains to be discussed.

\section{1 | Reflections on reactions}

In our analysis we found six themes: naturalized ideas about women in academia; reactions which shed light on how the goals and visions of the organization clash with more informal norms and ideas when the GE project was enacted; situations where a gender status quo was challenged; reactions to the feminist perspectives that the GE project brought with it; GE as the ethically right thing to do in the organization; and lastly how GE became a dilemma for the leadership during the project cycle. These are themes which overlap and this discussion will bring the themes together in dialogue.

As the project was introduced and implemented, there was a mixture of reactions from engagement to reluctance or resistance. The knowledge base for the project was a gender and norm-critical perspective and the aim of the project was to challenge discriminatory gendered norms. The project thus built on a different way of addressing gender inequality from how SLU had previously worked with this (Powell, 2016). Previously, GE measures built on a 'fix-the-womanidea' followed by courses and mentorship programmes aiming at helping women to advance in academia. The new perspectives met resistance, for example, when we were advised by the unit for further education not to label the project anything to do with gender, or not to use short-haired lesbian lectures in the course. The problem of gender inequalities in the organization was never denied during the project process. Quite the opposite, there was support from students (in surveys and in FGs), leadership representatives (in being part of the application process and the reference group), teachers (by taking part in the reference group and taking the course) and others (through workshops and meetings). Based on the empirical material from this project, as well as on previous studies from the Nordic countries (AroraJonsson, 2009; Melby et al., 2009; Skjeie \& Teigen, 2005), these positive reactions can be analysed as embedded in the discourse of GE being the ethically correct thing to do in a Swedish university. Still, the new (to SLU) way of addressing inequality here made visible contradicting ideas of what the problem was that needed to be solved, who was responsible and suitable to drive the process, and a gap between what was stated in policy and what was enacted in practice.

The problem formulation became visible in the analysis, for example, as naturalized roles were carved out for women and men. On several occasions, in interviews, meetings and in the course, people commented on parenthood and women losing interest in pursuing an academic career when they have children. There were also regular comments about women's lack of self-confidence which further strengthened the discourse of women themselves being the cause of gender inequalities.

The discourse where the problem of inequalities is identified shows a clash with what is formulated in formal SLU policy. It is likely that this informal discourse of GE influences decision-making on, for example, recruitment to positions, appointments to boards and also everyday but important events in academic life, such as being invited to give lectures, referee articles or supervise new PhD students.

The wish to have a GE project under the governmental funding that was offered for this project met positive reactions. Still, the responsibility for the project implementation and the placement of the same became silenced and sidelined. In line with one of the respondents who said that the leadership did not want to be too associated with these issues, the placement of the project can be interpreted as a way of handling a situation where you as a leadership on the one hand agree with the need to address inequality, but at the same time do not feel comfortable in being too close to it. The resistance to the feminist perspectives introduced by the project also occurred in less administrative situations than as in the previous example. For example, rather than saying that the feminist perspective was wrong, or in the wrong place, respondents mentioned the 'right' knowledge in this particular setting. We were, for example, told that we could not expect to teach anyone anything with our perspectives and through that comment a discourse on what was considered valuable knowledge in this setting was made explicit. This discourse 
re-emerged in a more formal setting as a comment was made about not becoming a 'gender university'. As this comment was made by a respondent on a leadership position, in a formal setting, what we at the time took as a personal view could also be interpreted as an official standpoint of the organization.

The complexity of reactions, from different actors in the organizations and in formal and informal situations, shows a discrepancy between formal discourses stated in SLU policy, where GE is depicted as central and important, and how GE and discrimination were addressed in informal and formal settings. Resistance took various forms in our empirical material, for example, co-option (e.g., when the project was handed over to a unit with limited interest and experience of GE), changing decisions (e.g., when the co-funding was withdrawn) and silence (e.g., when the support from the leadership decreased as the project came closer to the end of the project cycle). The last point here, the silencing, we interpreted as the leadership representatives who participated in the beginning of the project felt free to express personal views and engage until there were demands on them to provide more resources. When the funding was about to run out, and the stakes changed, those with the formal responsibility for GE at SLU distanced themselves from the project. The engagement that the project had experienced from the teachers that participated in the course was effectively quieted on two occasions towards the end of the project. The first time by questioning if we were to become a gender university, and the second time by ridiculing the person expressing his engagement at a formal meeting by saying: 'Oh that was a pitch.'

\subsection{Learning from resistance as discursive practices}

We categorized the reactions identified in the analysis and in this process we identified recurring discourses and we asked what can we learn from understanding resistance (and other reactions) as discursive practices, that is, what can be said, done and thought in the particular study context with regards to GE, at that particular point in time?

Resistance and engagement are discursive practices, that is, co-constructions of meaning in interaction. Categorizing the reactions to the project revealed the complexities of resistance, reinforcing the view of resistance as discursive practices. Treating resistance and engagement as stable binaries risks categorizing those for and against GE in an act of subjectification, limiting the potential for a deeper understanding of the causes of discrimination. The changing nature of reactions was made visible through analysing resistance 'done' in everyday life and embedded in formal and informal norms and structures. This analytical lens allowed identifying how resistance and engagement moved back and forth in sometimes unpredictable ways. It might seem paradoxical that what the GE project tried to enact was already stated in policy (i.e., agreed on as formal statements of how SLU should work with GE). But, our analysis shows a discrepancy between the formal discourse and the actual practice. In this study, there was no particular person or group that resisted or engaged more than others. Rather, this changed according to responsibility, position, demand for resources and time. Support for the project was greater in the early stages, before questions of continued funding (and financial obligations) were raised. As the mandate for allocating new funding is a question for leadership level, it does matter who is supporting and who is resisting GE at what point. In our analysis of reactions, we could uncover the organizational climate for GE by identifying how leadership representatives co-opted the aims of the project, changed decisions and expressed ideas and values contradictory to the policies in place.

Focusing our analysis on reactions, rather than on only resistance, enabled us to study change and changes in reactions and it enabled a more process-oriented analysis that revealed gaps where change is possible. To be able to study a process for a longer period as we have done here, and also keeping the focus on analysing reactions, we argue that it is possible to identify points in time where gendered discriminatory norms are more likely to occur. In our case the reactions changed from more engagement from the leadership in the start-up phase, to open resistance towards the end. But, in terms of the teachers, the reactions stayed more stable and the engagement that the course participants showed in the evaluation, in the workshop and in the finalizing meeting, showed a positive will to continue the work. We have argued here that the leadership have more financial and administrative responsibility, and that there is a reluctance to be too associated with GE, which might to a certain extent explain their unwillingness to support GE work. 
However, analysing discursive practices does not lead to change nor to action. But based on our analysis, we argue that demands for change must start with answering what problem we are trying to solve when we start a new GE project. That means, we have to, in a collaborative way, formulate the problem so that it is context specific and relevant. Otherwise, GE risks being the captive of consensus politics.

Overall, the responses to this particular GE project at a Swedish university provide clues to understanding gender inequality in academia as a whole. The entanglement of different discursive practices revealed by our contextual analysis shows potential to make visible normative practices hindering GE. The analysis can be helpful for others planning to run a GE project as it gives an idea of where the pitfalls might occur. The project shows the necessity of having a clearer idea of continuation and of each other's roles and responsibilities, long before the end of the project cycle, in order to avoid important ideas being co-opted or silenced.

\section{ACKNOWLEDGEMENTS}

This work would not have been possible without the thorough readings of the Gender, Work and Organization reviewers and editors. Thank you.

\section{DECLARATION OF CONFLICTING INTEREST}

The authors declared no potential conflicts of interest with respect to the authorship and/or publication of this article.

\section{ORCID}

Stina Powell 0 http://orcid.org/0000-0002-6898-1285

\section{REFERENCES}

Acker, J. (2006). Inequality regimes: Gender, class, and race in organizations. Gender \& Society, 20, 441-464.

Alnebratt, K., \& Jordansson, B. (2011). Jämställdhet, meritokrati och kvalitet - Ett triangeldrama i den akademiska vardagen. TGV, 2-3, 7-29.

Arora-Jonsson, S. (2005). Unsettling the order: Gendered subjects and grassroots activism in two forest communities. Uppsala, Sweden: SLU.

Arora-Jonsson, S. (2009). Discordant connections: Discourses on gender and grassroots activism in forest communities in India and Sweden. Signs, 35, 214-240.

Bacchi, C., \& Bonham, J. (2014). Reclaiming discursive practices as an analytical focus: Political implications. Foucault Studies, 17, 173-192.

Bacchi, C., \& Eveline, J. (2010). Mainstreaming politics: Gendering practices and feminist theory. Adelaide, Australia: University of Adelaide Press.

Bagilhole, B., \& Goode, J. (2001). The contradiction of the myth of individual merit, and the reality of a patriarchal support system in academic careers: A feminist investigation. European Journal of Women's Studies, 8, 161-180.

Ball, S. J. (1990). Politics and policy making in education: Exploration in policy sociology. New York, NY: Routledge.

Benschop, Y., \& Brouns, M. (2003). Crumbling ivory towers: Academic organizing and its gender effects. Gender, Work \& Organization, 10, 194-212.

Benschop, Y., \& Verloo, M. (2006). Sisyphus' Sisters: Can Gender Mainstreaming Escape the Genderedness of Organizations? Journal of Gender Studies, 15, 1-33.

Bothmer, R., Carlsson, M., \& Jennische, P. (2012). Vägval vid SLU, Report. Uppsala, Sweden: SLU.

Brown, W. (2000). Suffering rights as paradoxes. Constellations, 7, 230-241.

Carbin, M., \& Rönnblom, M. (2012). Gender equality in Swedish higher education. Depoliticised politics? Tidskrift för genusvetenskap, 1-2, 77-94.

Connell, R. (1997). Re-structuring gender: Comment on Hawkesworth's 'confounding gender'. Signs, 22, 702-707.

Connell, R. (2005). Hegemonic masculinity: Rethinking the concept. Gender \& Society, 19, 829-859.

Discrimination Act 2008:567. Arbetsmarknadsdepartementet. 
Edenheim, S., \& Rönnblom, M. (2012). Avskaffa jämställdhetspolitiken. In M. Eduards, M. Jansson, M. Wendt, \& C. Åse (Eds.), Det heter feminism!: 20 anspråksfulla förslag för att förändra världen. Antologi. Stockholm, Sweden: Hallongrottan och Feministiskt Perspektiv.

Eduards, M., Jansson, M., Wendt, M., \& Åse, C. (2012). Det heter feminism!: 20 anspråksfulla förslag för att förändra världen. Stockholm, Sweden: Hallongrottan.

Espersson, M. (2014). Isärkoppling som strategi. Om spänningen mellan meritokrati och likabehandlingsarbete vid ett svenskt lärosäte. In K. Sandell (Ed.), Att bryta innanförskapet. Makadam förlag: Lund, Sweden.

Ford, J. D., \& Laurie, L. W. (2009, April). Decoding resistance to change. Harvard Business Review.

Ford, P. J., Ford, L. W., \& D'Amelio, A. (2008). Resistance to change: The rest of the story. Academy of Management Review, 33, 362-417.

Gutiérrez y Muhs, G., Niemann, Y. F., Gonzalez, C. G., \& Harris, A. P. (2012). Presumed incompetent: The intersections of race and class for women in academia. Boulder, CO: Utah State University Press.

Hardy, C., \& Clegg, S. (2006). Some dare call it power. In S. Clegg, C. Hardy, T. B. Lawrence, \& W. R. Nord (Eds.), The SAGE handbook of organization studies (2nd ed.). London, UK: Sage.

Hollander, J. A., \& Einwohner, R. (2004). Conceptualizing resistance. Sociological Forum, 19, 533-554.

Honkanen, K. (2008). Equality politics out of the subaltern. In E. Magnusson, M. Rönnblom, \& H. Silius (Eds.), Critical studies of gender equalities. Nordic dislocations, dilemmas and contradictions. Stockholm, Sweden: Makadam.

Husu, L. (2005). Dold könsdiskriminering på akademiska arenor - Osynligt, synligt, subtilt (Rapport 2005:41 R). Stockholm, Sweden: Högskoleverket.

Lawton, A. (2000). The meritocracy myth and the illusion of equal employment opportunity. Minnesota Law Review, 85(587), 587-662.

Liinason, M. (2010). Institutionalized knowledge: Notes on the processes of inclusion and exclusion in gender studies in Sweden. NORA - Nordic Journal of Feminist and Gender Research, 18, 38-47.

Liinason, M. (2014). Shifts of power. An exploration of inequality regimes in academia. Tidskrift för genusvetenskap, 35, 75-97.

Lilja, M., \& Johansson, E. (2013). Understanding power and performing resistance: Swedish feminists, civil society voices, biopolitics and 'angry' men. Nordic Journal of Feminist and Gender Research, 21, 264-279.

Lombardo, E., Meier, P., \& Verloo, M. (2009). Stretching and bending gender equality: a discursive politics approach. In E. Lombardo, P. Meier \& M. Verloo (Eds.), The discursive politics of gender equality. New York: Routledge.

Lombardo, E., \& Mergaert, L. (2013). Gender mainstreaming and resistance to gender training: A framework for studying implementation. Nordic Journal of Feminist and Gender Research, 21, 296-311.

Magnusson, E., Rönnblom, M., \& Silius, H. (2008). Critical studies of gender equalities. Nordic dislocations, dilemmas and contradictions. Stockholm, Sweden: Makadam.

Mählck, P. (2013). Academic women with migrant background in the global knowledge economy: Bodies, hierarchies and resistance. Women's Studies International Forum, 36, 65-74.

Melby, K., Ravn, A.-B., \& Carlsson Wetterberg, C. (2009). Gender equality and welfare politics in Scandinavia. The limits of political ambition? Bristol, UK: Policy Press.

Mergaert, L., \& Lombardo, E. (2014). Resistance to implementing gender mainstreaming in EU research policy. European Integration online Paper (EloP) [Special issue 1, 18(Article 5, 1-21.

Pincus, I. (2002). The politics of gender equality policy: A study of implementation and non-implementation in three Swedish municipalities. Örebro, Sweden: Örebro University.

Powell, S. (2008). På väg mot ett genusintegrerat SLU, kartläggning och utvärdering av SLU: s forskning, utbildning och organisation inom genus och jämställdhet. Swedish University of Agricultural Sciences, report 255-278/08.

Powell, S. (2016). Gender equality and meritocracy. Contradictory discourses in the Academy. Thesis 2016:17. Uppsala: Swedish University of Agricultural Sciences.

Powell, S., \& Ah-King, A. (2013). A case study of integrating gender perspectives in teaching and in subject content at a natural science university in Sweden, International Journal of Gender, Science and Technology, 5, 52.

Powell, S., \& Arora-Jonsson, S. (2015). The Ethics of Political Correctness. In Understanding Social Science Research Ethics: Inter-disciplinary and Cross-Cultural Perspectives for a Globalising World, In K. Nakray, M. Alston and K. Whittenbury (Eds.), NY: Routledge.

Sandström, U., Wold, A., Jordansson, B., Ohlsson, B., \& Smedberg, A. (2010). Hans excellens: Om miljardsatsningarna på starka forskningsmiljöer. Stockholm, Sweden: Delegationen för jämställdhet i högskolan.

Skjeie, H., \& Teigen, M. (2005). Political constructions of gender equality: Travelling towards ... a gender balanced society? Nordic Journal of Women's Studies, 13, 137-197. 
SLU. (2012). Framtida utmaningar, SLU:s strategi 2013-2016 [Strategy 2013-2016].

Thomas, R., \& Davies, A. (2005). Theorizing the micro-politics of resistance: New public management and managerial identities in the UK public services. Organizational Studies, 26, 317-333.

Treleaven, L. (1998). Unsettling tensions: Gender, power and a new university (PhD thesis). University of Technology, Sydney. van den Brink, M. (2015). The politics of knowledge: The responses to feminist research from academic leaders. Equality, Diversity and Inclusion: An International Journal, 34, 483-495.

van den Brink, M., \& Benschop, Y. (2012). Slaying the seven-headed dragon: The quest for gender change in academia. Gender, Work and Organization, 19, 72-91.

Van den Brink, M., \& Benschop, Y. (2014). Gender in academic networking: The role of gatekeepers in professorial recruitment. Journal of Management Studies, 51, 460-492.

van den Brink, M., Brouns, M., \& Waslander, S. (2006). Does excellence have a gender? A national research on recruitment and selection procedures for professorial appointments in the Netherlands. Employee Relations, 28, 523-539.

Verloo, M., \& Lombardo, M. (2007). Contested gender equality and policy variety in Europe: Introducing a critical frame analysis approach. In M. Verloo (Ed.), Multiple meanings of gender equality: A critical frame analysis of gender policies in Europe. New York, NY: CPS Books Central European University Press.

Wahl, A., Holgersson, C., Höök, P., \& Linghag, S. (2008). Det ordnar sig. Teorier om organisation och kön. Lund, Sweden: Studentlitteratur. University of Technology.

Wullum Nielsen, M. (2015). New and persistent gender equality challenges in academia (Dissertation). Department of Political Science, Danish Centre for Studies in Research and Research Policy.

Stina Powell is a Researcher (PhD) and Head of Division on Environmental Communication at the Department of Urban and Rural Development, Swedish University of Agricultural Sciences. She lectures in gender and organizations, communication, sustainable development and environmental governance. Her present research focuses on problematizing and developing notions of meritocracy and gender equality in academia, as well as on interlinkages between the UN Sustainable Development Goals and gender equality and equity.

Malin Ah-King is an evolutionary biologist (PhD) and Associate Professor in Gender Studies at the Department of Ethnology, History of Religions and Gender Studies, Stockholm University. Her publications are concerned with interdisciplinary gender/biology research, by problematizing notions of biological sex as binary and stable, highlighting gender stereotypes and heteronormative conceptions in theory and research. They include publications in European Journal of Women's Studies, PLOS Biology and Trends in Ecology and Evolution. Her current project concerns 'The Female Turn in Evolutionary Biology' which explores how the international evolutionary research community radically shifted perspectives on the role of females in evolutionary biology.

Anita Hussénius is Director of the Centre for Gender Research at Uppsala University and Associate Professor in Chemistry at the University of Gävle, Sweden. Her main research interest is about gender and feminist perspectives on science and science education. More specifically, her research is focusing on cultural aspects, that is, discipline-specific values and underlying assumptions of what is regarded as important knowledge and skills, and how such values and assumptions are mediated explicitly as well as implicitly. Another action-oriented interest concerns science teachers' gender awareness and how an increased awareness of gender issues influence their teaching of science.

How to cite this article: Powell S, Ah-King M, Hussénius A. 'Are we to become a gender university?' Facets of resistance to a gender equality project. Gender Work Organ. 2017;1-17. https://doi.org/10.1111/gwao.12204 